\title{
An Analysis of Women Empowerment on Micro Business with Social Entrepreneurship Concept
}

\author{
Nurul Asfiah \\ Student of Postgraduate School of \\ Airlangga University \\ Email: asfi.1918@gmail.com
}

\author{
Muslich Anshori \\ Postgraduate School of Airlangga \\ University \\ Email: slich@feb.unair.ac.id
}

\author{
Imron Mawardi \\ Postgraduate School of Airlangga \\ University \\ Email:ronmawardi@feb.unair.ac.id
}

\begin{abstract}
This study aims to explore the phenomenon that arises in various socio-economic problems. The phenomenon raised from women entrepreneurs, with the category of Micro Enterprises. The subjects of the study were women entrepreneur program members of BUEKA (Economic Development of the 'Aisyiyah Family). This is an economic program of the 'Aisyiyah Organization. This is a qualitative study with a phenomenological approach. Data collection was performed by direct observation and detail report on various implementations of economic program designed to strengthen and improve entrepreneurship ability. In addition, the data were obtained through interview from key informant. The collected data were described to assess the women's economic empowerment program, resulting: 1) the pattern of MSE relationship with counseling agencies, 2) different pictures on the implementation of women empowerment as entrepreneur of MSE, and 3) implementation of social entrepreneurship concept in female entrepreneur group.
\end{abstract}

Keywords: MSEs, Social Entrepreneurship, and BUEKA

\section{INTRODUCTION}

Micro and Small Business Enterprises (MSEs) are one of the key actors of the national development process that has been proven their survival when crisis hitting the world. The empowerment and development of MSEs are the important alternative that could reduce the heavy burden faced by the national economy. Kartasasmita (1996) stated that MSEs is an important element in the development and planning of the concept of industrialization in developing countries, and laborintensive enterprises are important factors. This can at least be based on several reasons: (1) The actors of MSEs already have productive economy activities so that the need is the development and capacity-building rather than growth, making it easier and more certain to maintain; (2) If MSEs groups are empowered appropriately, they will easily move into small business sectors; (3) Effective development of MSEs could reduce the poverty suffered by the member themselves and it could even help the empowerment of the poor [1].
'Aisyiyah is a non-governmental organization that moves to strengthen social praxis. It is designed with three main pillars (education, health and economy). In the economic field, the movement is expected to provide economic and welfare solutions for the community. They built many units to generate income.'Aisyiyah movement also cares social problems by building orphanage, shelter home for street children and nursing home for abandoned person.

'Aisyiyah stated that the dignity of Indonesian women will not improve without economic progress. This encourages 'Aisyiyah to develop various business enterprises in the framework of economic empowerment developed under the BUEKA program. This is conducted to improve the life quality in society. UMK strengthening was done through capital, management, and technical operation to woman entrepreneurs joining BUEKA. As a women's movement, Aisyiyah is expected to actively contribute to the nation development through the three activities, determining the welfare of the nation. It also shows 'Aisyiyah respond to the SDG's (Sustainable Development Goals) agendas and implemented programs to increase women's participation in the economy. As part of the world community, Indonesia took a strategic role in mutually agreed programs, including in the strengthening of entrepreneurship for women. An entrepreneur as presented by Drucker (1985) has characteristics: confidence, task-oriented and result, risk-taking, leadership, originality, future-oriented, and honest and diligent [2].

As a social movement, 'Aisyiyah has its own characteristic of forming a social entrepreneur, not only thinks and acts for profitability in running his business, but has social values. The concept of social entrepreneur has been implemented by Robert Owen. He contributed most of his business profits to improve his employees' living standards, so he is known as the Father of the world cooperative movement [3]. Social entrepreneurship is an effort that has a responsive character and empathy for social issues and uses the ability of entrepreneurship to make social change, particularly in the areas of welfare, education and health, as quoted in many literature [4]. Therefore 'Aisyiyah through BUEKA program will strengthen women social entrepreneurship to achieve mutual prosperity. 


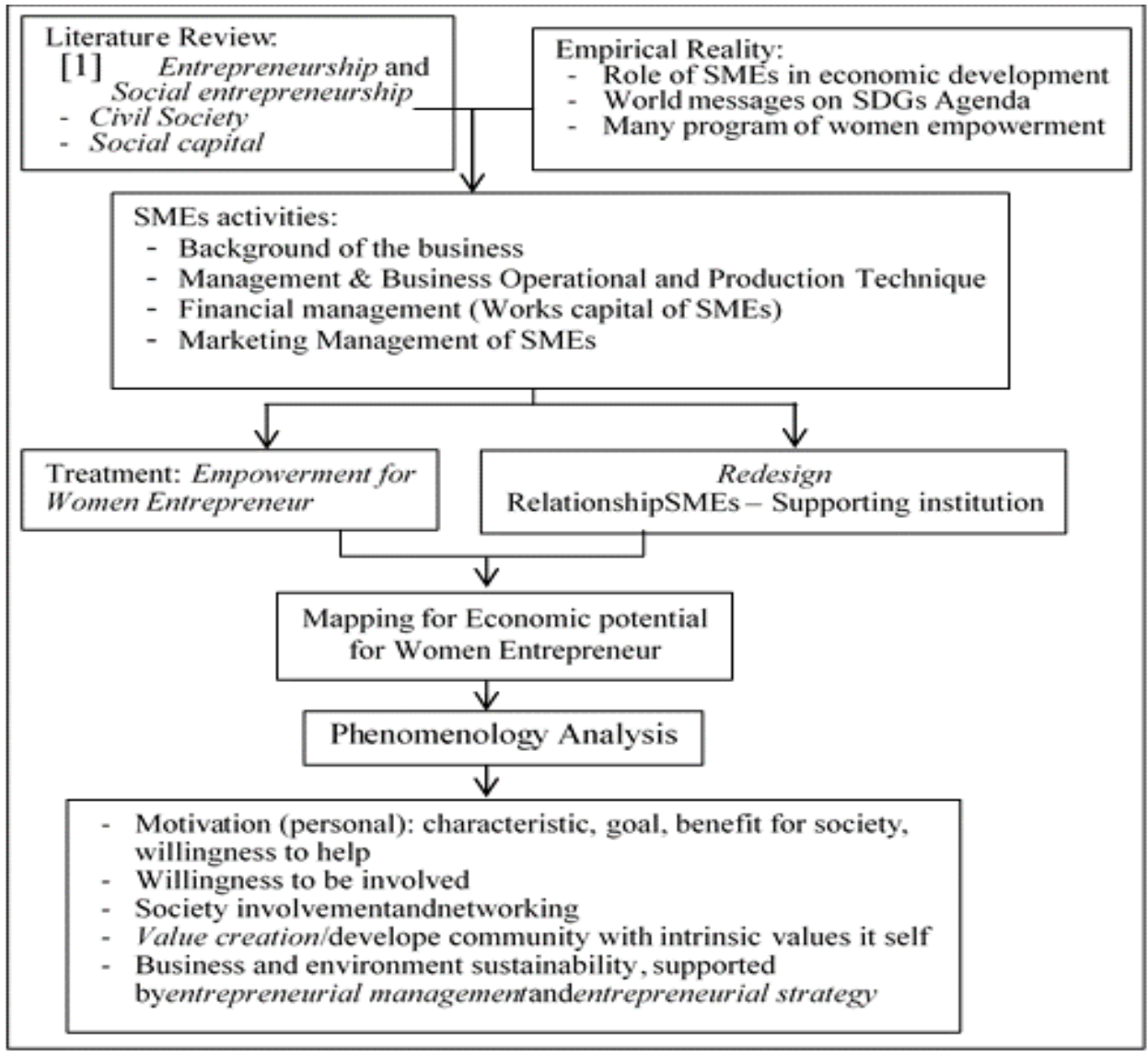

Figure 1. Research Framework

'Aisyiyah needs to respond to the nation's economic problems by redesigning all aspects of the organization management of MSEs, so as to be able to drive the business wheel optimally. Therefore, empowering the community, particularly women, will have a direct impact on the welfare of families and communities by providing strengthening of human capital, so that women social entrepreneurship plays a key role to economic resilience. Effort that runs optimally could be done by strengthening knowledge, experience, capability, skill, creativity \& innovation [5]. This social entrepreneurship can generally be implemented in the community economy as has been done by BUEKA.

\section{METHOD}

This research implemented qualitative study, emphasizing on the "depth" and not the "breadth" of a problem, with phenomenology [7]. Expressing socioeconomic symptom which emphasize on phenomenon of socio-economic of woman entrepreneur joined in BUEKA. Data were collected comprehensively by indepth interview with interview guide and participative observation. The linkage of theoretic, data collection methods, and data analysis methods into one relation, as well as data analysis techniques were performed to result in in-depth and extensive investigation outcomes. In its function as data analysis, according to Creswell (1998), this phenomenological approach postponed all judgments about natural attitudes until found a certain basis, called epoche [7]

\section{RESULT}

This research was conducted in the women's organization 'Aisyiyah. The vision and determination of the "Aisyiyah movement is the occurance of a society prosperous, fair and justice, prosperous and safe in order to achieve happiness. The view of 'Aisyiyah is prosperous society with the pleasure of Allah, that is a society that leads its citizens to happiness both of the world and the hereafter, termed falah, [8].

The 'Aisyiyah women's movement was organized with a leadership structure ranging from the Central Leadership based in Yogyakarta, and subordinate for provincial level followed by city and then the village level (www.aisyiyah.or. id).[9]

\section{Advancement of Women's Movement}

'Aisyiyah as an organization was born on May 19th, 1917 or coinciding with the date of 27 Rajab in 1335 years Hijriyah. 'Aisyiyah Proselytizing (da'wah) 
proclaimed to strengthen Social Praxis Movement committed to the Three Pillars (education, health and economy) movement. In the economic field, the movement is expected to provide economic solutions by improving the welfare for society. 'Aisyiyah Vision is to actualize the sturdy Islam and the real Islamic society through the strengthening and development of $d a$ 'wah amar ma'ruf nahi munkar. 'Aisyiyah Regional Leadership has 34 Regional Leaders, and East Java is considered well done.

'Aisyiyah has experience and contribution to the advancement of Indonesia women in various basic life areas: education, health, economy, social politics, environment and law. The East Java Regional Leader is as a pioneer in the implementation of various programs from the Central Leadership. To promote the degree equality of women and to encourage women's participation in the economic field, East Java Regional Leader has established 568 female cooperatives. 'Aisyiyah encourages the establishment of Baitul Maalwat-Tamwil (BMT) and conducts coaching on home-industry, as published in http://jatim.aisyiyah.or.id[10]

Entering the second century, 'Aisyiyah held a Congress and initiated the jargon "The Advancement Women" and promote fourth pillar: Women's Economic Empowerment, at the 'Aisyiyah National Tanwir. They designed 'Aisyiyah's program, particularly on women's and economic roles in facing global challenges.

Table 1. Types of National Program Business and Production of BUEKA

\begin{tabular}{|c|c|c|}
\hline No & Name & Description \\
\hline 1 & Melin@ & $\begin{array}{l}\text { Producing and distributing environmentally } \\
\text { friendly detergent products with Melin and } \\
\text { Eklin brand for household }\end{array}$ \\
\hline 2 & Delfit@ & $\begin{array}{l}\text { Producing local processed soybean using } \\
\text { modern machine }\end{array}$ \\
\hline 3 & Parka@ & $\begin{array}{l}\text { Improving the ability in optimalizing the } \\
\text { land use around the house began from the } \\
\text { preparation of infrastructure until planting }\end{array}$ \\
\hline 4 & Rias@ & $\begin{array}{l}\text { Improving skills in providing makeup } \\
\text { services in the community for various events }\end{array}$ \\
\hline 5 & $\begin{array}{l}\text { TKI } \\
\text { Purna }\end{array}$ & $\begin{array}{l}\text { Provides training and mentoring for families } \\
\text { and migrant workers to become an } \\
\text { entrepreneurs }\end{array}$ \\
\hline 6 & SWA & $\begin{array}{l}\text { Running School of Aisyiyah } \\
\text { Entrepreneurship Program, by providing } \\
\text { education, training and mentoring to } \\
\text { prospective entrepreneurs, new entrepreneurs } \\
\text { as well as those who have run business in } \\
\text { small and micro groups }\end{array}$ \\
\hline 7 & KUKA & $\begin{array}{l}\text { Program of Family Business Clinic of } \\
\text { 'Aisyiyah (KUKA) for the running small and } \\
\text { micro entrepreneurs }\end{array}$ \\
\hline 8 & $\begin{array}{l}\text { BUEKA } \\
\text { BSA }\end{array}$ & $\begin{array}{l}\text { The extension or expansion of the BUEKA } \\
\text { program for public in need of health and } \\
\text { economic strengthening, regardless of } \\
\text { religion, ethnicity or belief. The BSA } \\
\text { program was initiated by the MAMPU } \\
\text { Program, an Ausaid - Indonesia Partnership } \\
\text { for Gender Equality and Women } \\
\text { Empowerment program }\end{array}$ \\
\hline
\end{tabular}

Potential Economic and Independent Women

'Aisyiyah has collected and recorded entrepreneur women named IPAS (i.e. Association of 'Aisyiyah Entrepreneurs). They focus on improving the quality of women life, to reach the family which is sakinah with qaryah thayyibah. They will be independent, supported by economic capacity strengthening and empowerment of IPAS through BUEKA Program based on local wisdom.

\section{"Women Social Entrepreneurship"}

Entrepreneurs are individuals who are able to sense opportunities, find and pursue desired opportunities in different life situations, and believe that success is possible. These three elements distinguish individuals from the majority of the people, with the ability to see opportunities that are often based on deep personal knowledge and experience, both in producing the product over the years as well as marketing it. However, the desire to pursue opportunities on the part of the individual is often the result of a complex balance of risks and outcomes that are complex and balanced between the risks and the success that will be achieved (Sarif, 2013).[11]

Women's empowerment, according to Friedman (1992), covers three main points, 1) as an enabling process (2) empowering, and 3) advocation to protect and support women in rural areas. Empowerment makes women have control over their life scenarios, including control over resources, ideology, increased confidence and the transformation of their inner ability to deal with external affairs. Women's empowerment is not only essential for women's well-being but also important for the development of a country (Shaheen, 2013; Sharma \& Verma, 2008).[12]

Women empowerment conducted by 'Aisyiyah for women entrepreneurs who are members of IPAS, is performed through SWA - BSA program, a new one. In addition, the East Java Economic and Labor Assembly also launched the PPU Program (Center for Business Development), with the aim to accelerate the realization of economic empowerment which has been done with the expectation of MSE to immediately go up to class, as presented by Kartasasmita (Siregar, 2006).[1]

The Aisiyah movement formulated affirmative action by re-formulating a significant state of mind to strengthen the three pillars that have been built so far (i.e. education, health and economics), refining with the fourth pillar of economic empowerment of women. 'Aisyiyah made a resolution on the economic movement of women entering the second century by taking part in the praxis movement to actualize ideologically outlined as contained in Al-Maun's theology. Empowering and prospering are not letting the weak fell into the poverty. This is an inherent part of the awareness of thinking and acting in economic and business movements, a strengthening movement in the network of economic empowerment, involving Micro and Small Enterprises (MSEs) with the accompanying institutions. 
Spirit in social entrepreneurship is the mental / attitude of a person, which not only requires the process of invention and application of innovation, but also has creativity in the discovery of business opportunities as well as the courage to take risks. The motivation for social entrepreneur is very complex, which has high income security, and is able to give many important meaning for social purpose, such as altruism and ethics, social alignment and ideological purpose (Prabhu, 1999; Spear, 2006; Hudson, 2009; in Humbert, 2012). [13] In addition, this motivation is also related to the problem of how to deal with obstacles such as ethnicity and gender.

\section{CONCLUSION}

'Aisyiyah movement with a motive to raise awareness of religion and society, and invite its citizens to reach baldatun thayyibatun warabbun ghafur society, a happy and prosperous life full of God's mercy and blessings. 'Aisyiyah maintains the dignity of Indonesian women will not improve without economic improvement. Human beings are mandated to be the Caliph on earth. they have to be responsible for the survival and sustainability of life, and therefore must be the best people (khairu ummah). It will be realized if they are able to develop self-potential through the development of knowledge, treasure, and physical and spiritual health. So, they benefit as other people and environment.

Economic is a fundamental issue in human life. Economic independence should be started from the family economic capacity. Implementation of the program is tailored to environmental development, in accordance with local wisdom in every place. Women empowerment program for women entrepreneurs is to enhance women's awareness and skill to realize civil society which is qaryah thayyibah through social entrepreneurship concept. It requires strong intention, in order to involve themself as a social entrepreneurship.

A woman is likely to be independent if she has a high social motivation. The feminist soul, merely "money oriented" that make women more like "mothers" of community. Social entrepreneurship is a new phenomenon in various countries to reduce social problems and eradicate massive poverty. 'Aisyiyah drives that phenomenon by connecting established entrepreneurs and successive start-ups to other related agencies, such as Financial Institutions or Work Centers, to build cooperation. The program is better assisting in operations and management techniques, either manually or online.

\section{REFERENCES}

[1] Kartasasmita, G., Pembangunan Untuk Rakyat: Memadukan Pertumbuhan dan Pemerataan. Jakarta: CIDES; Siregar, Hermanto. 2006,Kongres XVI Ikatan Sarjana Ekonomi Indonesia (ISEI). Manado, 1996

[2] Drucker, Peter, Innovation and
Entrepreneurship: Practice and Principles. New York: William Heinemann Ltd., 1985

[3] https://id.wikipedia.org/wiki/Robert_Owen

[4] Thompson, J.D., I.C. MacMillan, 2010, Making Social Ventures Work, Harvard Business Review, 09, 2010

[5] Malone, Edwinson, Intellectual Capital and Innovation Performance: Empirical Evidence in the Turkish Automotive Supplier; Journal of Technology Management and Innovation, 1997

[6] Denzin, Norman K., And Yvonna S. Lincoln, Handbook of Qualitative Research, Sage Publiction, Pvt. Ltd., 1997, Edisi Bahasa Indonesia, Pustaka Pelajar.2009

[7] Bungin, Burhan, Penelitian Kualitatif, Edisi Kedua, Prenada Media Group, Jakarta, 2014

[8] Misanam, Munrokhim, M.A.Ec., Ph.D., Priyonggo Suseno, S.E., M.Sc., M. Bhekti Hendrieanto, S.E., M.Sc., Ekonomi Islam, hal. 2,2014

[9] www.aisyiyah.or.id/www.aisyiyah.or.id/

[10] http://jatim.aisyiyah.or.id/id/syiar.html

[11] Sarif, Suhaimi Mhd., and Abdullah Sarwar and Yusof Ismail, Practice of Social Entrepreneurship among the Muslim Entrepreneurs in Malaysia; Middle-East Journal of Scientific Research 14 (11): 14631470, 2013

[12] Shaheen, Imrab and Sajid, Mushtaq and Batool, Qudsia, Role of Microenterprises with Regard to Economic Empowerment of Women, International Journal of Management Sciences and Business Research, Volume 2, Issue 8, 2013.

[13] Humbert, Anne Laure, (2012), Women As Social Entrepreneurs, Third Sector Research Centre, University of Birmingham; Birmingham; Informing Civil Society, info@tsrc.ac.uk; www.tsrc.ac.uk 